\title{
Constitutional Recognition or treaty?
}

\author{
Carla Sullivan
}

University of Technology Sydney, Faculty of Arts and Social Sciences, PO Box 123, Ultimo NSW 2007, Australia. carla.sullivan@student.uts.edu.au

In 2017, the Uluru Statement from the Heart was released during the Uluru First Nations Convention. In it, 250 Aboriginal and Torres Strait Islander delegates made a powerful statement endorsing constitutional reform to enshrine an Indigenous voice in Australian Parliament and in the Australian Constitution, as well as the establishment of a Makaratta Commission to supervise the subsequent legislative change and 'truth-telling' that would enshrine a First Nations Voice in Australia's Constitution. While the Uluru Statement from the Heart was a culmination of many years of grassroots campaigning and activism, there remains dissent over whether constitutional recognition could be as effective as a treaty.

A treaty, unlike constitutional recognition, is an agreement or settlement that is entered into by sovereign states after a process of negotiation and would allow for Indigenous Australians to have a legally binding instrument that supports their rights and recognises their culture. Unlike constitutional recognition, a treaty would recognise Indigenous Australians as a sovereign, and could serve to enact agreements that 'can see greater self-government rights transferred to Aboriginal people without the need for constitutional change' (Gusser 2017, p. 9). Further, a treaty would impose sanctions for breaches, as it establishes a relationship bound by law and convention as opposed to symbolic dealings.

To consider constitutional reform in Australia, I think that it is important to consider how constitutional reform was achieved in other nations, and how successful it has been in protecting First Nations people. For instance, in Canada, Part II of their Constitution was amended in 1982 under the Constitution Act in order to identify specific existing Indigenous rights and treaties, while also allowing for Canada to make laws 'for the peace, order and good government of Canada in relation to Indigenous Canadians' (Gusser 2017, p.15). However, this constitutional reform was only achieved after the Nanfan Treaty had been signed, and after wide-scale campaigning and lobbying to international rights (Gusser 2017, p. 16). 
In this instance, constitutional recognition was achieved in part because there had been an existing treaty that had supported the recognition of Indigenous Canadian rights. Hence, I believe that a treaty and constitutional recognition are not mutually exclusive. Rather, both of these models could act in tandem to support the recognition of Indigenous Australians, and in turn, provide the recognition that is needed to support Indigenous Australian identity (Taylor 1992).

\section{References}

Gussen, B. 2017, 'A Comparative Analysis of Constitutional Recognition of Aboriginal Peoples, Melbourne University Law Review, vol. 40, no. 3, pp. 15-19.

Taylor, C. 1992, 'The Politics of Recognition' in Multiculturalism and "the Politics of Recognition”: An Essay, Princeton University Press, pp. 25-73. 